\title{
Biotransformation of 6-Deoxotyphasterol in a Liverwort, Marchantia polymorpha
}

\author{
Young-Soo Kim, Tac-Wuk Kim, and Scong-Ki Kim* \\ Department of Life Science. Chang-Ang Universit; Seonl 156-756. Korea \\ Received Jily /1.2003
}

Key Words : Brassinosteroids, Biotransformation, 6-Deoxoty phasterol, Liverwort. Marchanta polymorpha

$\Lambda$ series of our researches revealed that a Bryophyc, Manchantia polymorpha, contained steroidal plant hornones, collectively named brassinosteroids (BRs), such as 6-deoxocastasterone (7), castasterone (8) and brassinolide (9), ${ }^{1.2}$ and potent biosynthetic precursors of the BRs, campesterol (1) and campestanol (2). ${ }^{\hat{j}}$ Together with demonstrating the presence of a biosynthetic sequence, $7 \rightarrow \mathbf{8} \rightarrow \mathbf{9}$, the result strongly suggested that a biosynthetic pathway from $\mathbf{I}$ to 9 via 2.7 and 8, so called the C.6-oxidation pathway found in higher plants, ${ }^{4-8}$ is operative to produce BRs in the lower plants (Fig. 1)." Nevertheless, biosynthetic intermediates between 2 and 7 in the C6-oxidation pathway have not been identilied from the lower plant, so that the precise pathway to synthesize 7 from 2 in $M$ polymorpha still remains to be elucidated. This prompted us 10 investigate in vive and in vitro conversion(s) of $\left|26,28-{ }^{2} \mathrm{I}_{6}\right|-$ and $\mid{ }^{2}\left[\mathrm{I}_{0} \mid-6\right.$-deoxotyphasterol (6), a potent biosynthetic precursor of 7 , in cultured cells of $M$. potvmorpha in this study, ${ }^{(1)} .11$ which gives information on biosynthetic processes for $A$-ring hydroxylation to produce the BRs identilied from the lower plant.

First, $\left.\right|^{2}[]_{6} \mid-6$ was led to the media of suspension cultured cells of $M$. polvmorpha to investigate in vivo conversion of 6 in the lower plant. After incubation for 7 days, the cells were harvested and extracted with $80 \%$ methanol followed by chlorofom. The extract was reduced to aqueous phase, combined with the media, and purified by column chromato- graphies by the guidance of the rice lamina inclination assay. ${ }^{12}$ The final purilication for metabolites of $\left[{ }^{2} \mathrm{H}_{6} \mid-6\right.$ was catricd out by a reversed phase IJPLC. The obtained IJPLC fractions were analyzed by a Preparative TLC, giving rise to BR-like purple-bluish spots in the I IPLC Iraction 42.43.5052, 55 and 56. Among them, the fraction 55 and 56 was correspondent to the retention time of $\left[{ }^{2}\right]\left[_{6} \mid-6\right.$ added as a substrate, proposing that the active compounds in the fraction 42,43 and 50-52 were metabolites of $\left.\left.\right|^{2} \mathrm{I}_{6}\right]-6$ in the Marchontia cells. The fractions were thus derivatized to be a methaneboronate (MB) or MB-1rimethylsilylic ether (TMSi). and then analyzed by GC-MS/Sclected Ion Monitoring (SIM).

As summarized in Table 1, a bis-MB (BMB) of the active compound in the fraction 42 and 43 showed characteristic ions for $\left.\left[{ }^{2}\right] \mathrm{I}_{6}\right]-7 \mathrm{BMB}$ at $m / z 504\left(\mathrm{M}^{\prime}, 39 \%\right), 489$ (13). 273 (100) and 161 (34) at the same GC retention time as that of authentic $\left[{ }^{2} \mathrm{I}_{6} \mid-7\right.$ BMB. $\triangle \mathrm{MB}$ of one of the active compounds in the fraction 50-52 gave a mass spectrum at $m / s 462(\mathrm{M}$, $47 \%), 447(7), 385(5), 301(8), 246(12), 231$ (100) and 161 (45) whose mass spectrum and GC retention time were identical to those of authentic $\left.\right|^{2} \mathrm{H}_{6} \mid-6$-decoxo-3-dehydroteasterone $\left.\left({ }^{2} \mathrm{I}_{6}\right]-5\right) \mathrm{MB}$. In addition, a MB-TMSi cther of other active compound in the firaction appeared the same mass spectrum at $m / 5536(\mathrm{M}, 45 \%), 521$ (42), 479 (19), 446 $(20), 431$ (29), $305(28), 215(100)$ and 161 (41) at the equal

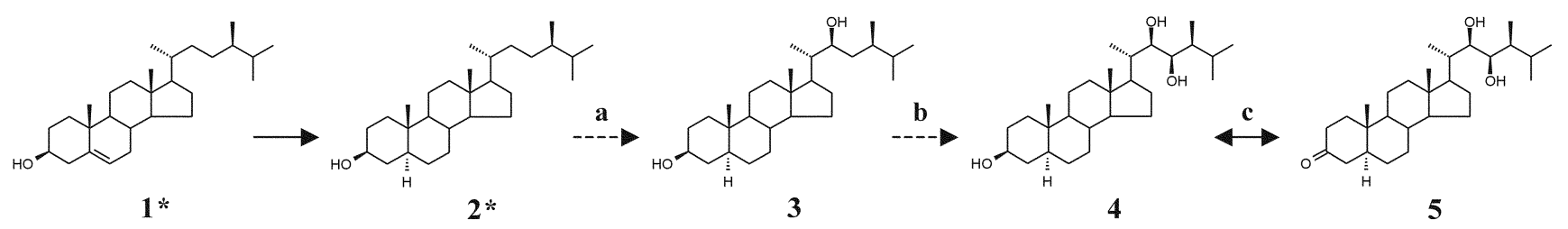

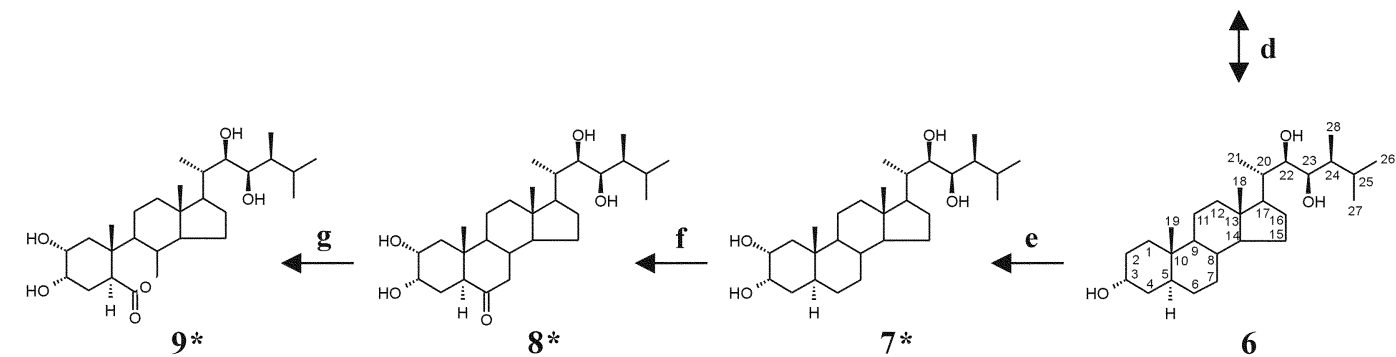

Figure 1. The late (6-oxidation pathway to produce BRs possibly involved in $\mathrm{H}$. polwmorpha. Asterisks indicate steroids identified from $\mathrm{H}$. polmorpha. Dashed arrows indicate steps which are not veritied yet. 1. campesterol; 2. campestanol; 3. 6-deoxocathasterone; 4. 6deoxoteasterone: 5. 6-deoxo-3-dehydroteasterone: 6. 6-deoxotyphasterol; 7. 6-deoxocastasterone; 8. castasterone: 9. brassinolide: a. 2 22Rhydroxylase: b. 323 R-hydroxylase: c. 4 dehydrogenase: d. 5 reductase: e. 62 a-hydroxylase: $f$. 7 oxidase: g. 8 oxidase. 
Table 1. HPLC and GC-MS data for identified BRs as in wino and in vino metabolites in 1 . polvmorpha

\begin{tabular}{|c|c|c|c|}
\hline Compound & $\mathrm{Rt}^{\prime}$ on $\mathrm{HPLC}$ & $\mathrm{Rt}^{1}$ on $\mathrm{GC}$ & Prominent ions ( $m: z$, relative intensity $\%$ ) \\
\hline Authentic $4^{2}$ & $50-52$ & 14.02 & $530\left(\mathrm{M}^{+}, 49\right), 515(44), 473(17), 440(17), 425(29), 305(28), 215(100), 155(41)$ \\
\hline Authentic $\left[{ }^{2} \mathrm{H}_{6}\right]-4^{*}$ & $50-52$ & 13.78 & $536\left(\mathrm{M}^{+}, 50\right), 521(46), 479(17), 446(18), 431(29), 305(28), 215(100), 161(42)$ \\
\hline Authentic $5^{3}$ & $50-52$ & 14.18 & $456\left(\mathrm{M}^{+}, 51\right), 441(6), 385(4), 301(7), 246(12), 231(100), 155(47)$ \\
\hline Authentic $\left[{ }^{2} \mathrm{H}_{6}\right]-5^{3}$ & $50-52$ & 13.91 & $462\left(\mathrm{M}^{+}, 46\right), 447(6), 385(4), 301(8), 246(12), 231(100), 161(44)$ \\
\hline Authentic $6=$ & 55,56 & 12.22 & $530\left(\mathrm{M}^{+}, 23\right), 515(4), 479(3), 440(48), 425(49), 305(12), 215(100), 155(29)$ \\
\hline Authentic $\left[{ }^{2} \mathrm{H}_{6}\right]-6^{2}$ & 55,56 & 12.01 & $536\left(\mathrm{M}^{+}, 23\right), 521(3), 479(2), 446(47), 431(48), 3(05(12), 215(100), 161(29)$ \\
\hline Authentic $7^{+}$ & 42,43 & 14.47 & $498\left(\mathrm{M}^{+}, 39\right), 483(15), 273(100), 155(34)$ \\
\hline Authentic $\left[{ }^{2} \mathrm{H}_{\mathrm{r}}\right]-7^{+}$ & $42,4 \hat{3}$ & 14.22 & $504\left(\mathrm{M}^{+}, 40\right), 489(14), 273(100), 161(34)$ \\
\hline Identified $4^{2}$ & $50-52$ & 14.02 & $530\left(\mathrm{M}^{+}, 44\right), 515(42), 473(23), 440(23), 425(33), 305(31), 215(100), 155(38)$ \\
\hline Identified $\left[{ }^{2} \mathrm{H}_{b}\right]-4^{2}$ & $50-52$ & 13.78 & $536\left(\mathrm{M}^{+}, 45\right), 521(42), 479(19), 446(20), 431(29), 305(28), 215(100), 161(41)$ \\
\hline Identified $5^{3}$ & $50-52$ & 14.18 & $456\left(\mathrm{M}^{+}, 52\right), 441(3), 385(5), 301(8), 246(10), 231(100), 155(37)$ \\
\hline Identitied $\left[{ }^{*} \mathrm{H}_{6}\right]-5^{\hat{3}}$ & $50-52$ & 13.91 & $462\left(\mathrm{M}^{+}, 47\right), 447(7), 385(5), 301(8), 246(12), 231(100), 161(45)$ \\
\hline Identified $6^{2}$ & 55,56 & 12.22 & $530\left(\mathrm{M}^{+}, 23\right), 515(5), 479(4), 440(47), 425(48), 305(12), 215(100), 155(30)$ \\
\hline Identitied $\left[{ }^{2} \mathrm{H}_{5}\right]-6^{2}$ & 55,56 & 12.01 & $536\left(\mathrm{M}^{+}, 24\right), 521(4), 479(3), 446(46), 431(47), 305(12), 215(100), 161(29)$ \\
\hline Identified $7^{4}$ & 42,43 & 14.47 & $498\left(\mathrm{M}^{+}, 36\right), 483(14), 273(100), 155(35)$ \\
\hline Identitied $\left[{ }^{\hat{H}} \mathrm{H}_{6}\right]-7^{\wedge}$ & 42,43 & 14.22 & $504\left(\mathrm{M}^{+}, 39\right), 489(13), 273(100), 161(34)$ \\
\hline
\end{tabular}

1: Retention time (min). 2: The sample was analyzed as a methanboronate (MB)-trimethylsilylic ether (TMSi). 3: The sample was analyzed as a methanboronate (MB). 4: The sample was analyzed as a bismethanboronate (BMB).

GC retention time to that of authentic $\left[{ }^{3} \mathrm{H}_{6}\right]-6$-deoxoteasterone $\left(\left[{ }^{3} \mathrm{H}_{6}\right]-4\right)$ MB-TMSi ether. In consequence, $\left[{ }^{\hat{}} \mathrm{H}_{6}\right]-4$. -5 and -7 were identified as metabolites of $\left[{ }^{-3} \mathrm{H}_{6}\right]-6$. which indicated that 6 could be transformed into 4.5 and 7 in the Manchantia cells.

Next. in vito conversion of 6 was investigated by the use of a crude enzyme solution prepared from the cultured cells of $M$. potymorpha. Because endogenous amount of BRs in the cells ( $15 \mathrm{~g}$ ) was negligible. ${ }^{11}$ non-deuterium labeled $\left(\left[{ }^{3} \mathrm{H}_{i}\right]\right) 6$ was used as a substrate, and deuterium labeled expected products. $\left[{ }^{3} \mathrm{H}_{6}\right]-\mathbf{4}, \mathbf{- 5}$ and $\mathbf{- 7}$. were added for quantitative analyses after finishing enzyme assays. The enzyme products were extracted and purified by the methods described in Experimental Section, and the HPLC fractions 42. 43 and $50-52$ from which in wivo metabolites of $\left[{ }^{\hat{2}} \mathrm{H}_{6}\right]-6$. $\left[{ }^{3} \mathrm{H}_{6}\right]-4 . \quad-5$ and -7 were detected, were analyzed by a capillary GC-MS/SIM. In the HPLC fraction 42 and 43 . BMB of the enzyme product showed mass ions at $m z 498$ $\left(\mathrm{M}^{+}, 36\right) .483$ (14). $273(100)$ and 155 (35) that were detected at the same $\mathrm{GC}$ retention time as that of authentic 7 BMB (Table 1). In the HPLC fraction 50-52. a MB-TMSi and $\mathrm{aB}$ of the product gave the identical mass spectrum and GC retention time to those of authentic 4 MB-TMSi and $5 \mathrm{MB}$. respectively (Table 1). Coupled with the result obtained from in wivo feeding experiment. these revealed that 6 was converted into 7 by $2 \alpha$-hydrosylation and 4 via 5 by C6-oxidation and C3-epimerization. Therefore. the presence of a biosynthetic sequence. $4 \leftarrow 5 \leftarrow 6 \rightarrow 7$, was demonstrated in the cells (Table 2).

In the late C6-oxidation pathway 3-epimerization of 4 to 6 via 5 is known to be a reversible reaction. ${ }^{11.13}$ Thus. the presence of $6 \rightarrow 5 \rightarrow 4$ strongly suggested that a reversed reaction of the sequence can be also functional in the Marchontia cells. To confirm that enzymatic conversions of 4 and 5 in the cells were subsequently performed. When 4 was added to the enzyme solution as a substrate. 5 and 6 were identified as the products. When 5 was used. 4 and 6
Table 2. Enzymatic conversions of BRs in the cells of $M$. polymoipha

\begin{tabular}{|c|c|c|c|c|}
\hline \multirow{2}{*}{ Substrate } & \multirow{2}{*}{ Product(s) } & \multicolumn{2}{|c|}{ Enzyme } & \multirow{2}{*}{ - Biosynthetic Sequencers) } \\
\hline & & Name & $\overline{\text { Activity }}$ & \\
\hline \multirow[t]{3}{*}{6} & 7 & e & 23.5 & $6 \rightarrow 7$ \\
\hline & 5 & d & $\mathrm{ND}^{b}$ & $5 \leftarrow 6$ \\
\hline & 4 & $d, c$ & $\mathrm{ND}^{b}$ & $4 \leftarrow 5 \leftarrow 6$ \\
\hline \multirow[t]{2}{*}{5} & 4 & c & $\mathrm{ND}^{b}$ & $4 \leftarrow 5$ \\
\hline & 6 & d & 57.9 & $5 \rightarrow 6$ \\
\hline \multirow[t]{3}{*}{4} & 5 & c & 1000 & $4 \rightarrow 5$ \\
\hline & 6 & c, d & $\mathrm{ND}^{b}$ & $4 \rightarrow 5 \rightarrow 6$ \\
\hline & & & & Sum : $4 \leftrightarrow 5 \leftrightarrow 6 \rightarrow 7$ \\
\hline
\end{tabular}

${ }^{a}$ Enzyme acticity is expressed as ng product mg protein ${ }^{-1} \mathrm{~min}^{-1}$. $\mathrm{ND}$ : Not determined.

were characterized to be the products (Table 2). These indicated that conversions of $4 \rightarrow 5 \rightarrow 6$ and $4 \leftarrow 5 \rightarrow 6$ also occurred in the cells. proofing the presence of a reversible 3epimerization of 4 to 6 via $5,4 \leftrightarrow 5 \leftrightarrow 6$. in the Marchantia cells.

The activity of enzymes mediating the conversion of 4 to 6 via 5 and 6 to 7 , namely 4 dehydrogenase (c). 5 reductase (d) and $62 \alpha$-hydroxylase (e). respectively. in the Marchantia cells calculated by the ratio of the products to the internal standards $\left(\left[{ }^{-} \mathrm{H}_{6}\right]-4,-5\right.$ and -7$)$ added was 100.0 .57 .9 and $23.5 \mathrm{ng} \mathrm{mg}$ protein ${ }^{-1} \mathrm{~min}^{-1}$. respectively, which are much higher than that of 7 oxidase (f. $5.9 \mathrm{ng} \mathrm{mg}$ protein ${ }^{-1} \mathrm{~min}^{-1}$ ) and 8 6-oxidase (g. $0.6 \mathrm{ng} \mathrm{mg}$ protein ${ }^{-1} \mathrm{~min}^{-1}$ ) previously determined in the cells. This probably means that 4 is quickly converted into 7 via 5 and 6 . but the next conversion of 7 to 9 via 8 slowly occurs. For the reason. the endogenous level of 7.8 and 9 seems to be kept higher than those of 4.5 and 6 in the Marchantia cells. which probably allowed us to identify 7.8 and 9 but not 4.5 and 6 from $M$ polymorpha.

Although 4,5 and 6 has not been identified from $M$. polymorpha. the presence of a biosynthetic sequence of BRs. $4 \leftrightarrow 5 \leftrightarrow 6 \rightarrow 7$, in the Marchantia cells was 
demonstrated by in wwo and witro conversions in this study. Because the presence of biosynthetic sequences. $1 \rightarrow \mathbf{2}$ and $7 \rightarrow 8 \rightarrow 9$. was already verified in the cells. ${ }^{1-3}$ the result indicates that $M$ polymorpha contains biosynthetic sequences. $1 \rightarrow \mathbf{2}$ and $\mathbf{4} \leftrightarrow \mathbf{5} \leftrightarrow 6 \rightarrow 7 \rightarrow \mathbf{8} \rightarrow 9$. to produce BRs. These biosynthetic sequences are included in the C6oxidation pathway established in higher plants. which suggests that the same biosynthetic pathway in higher plants is working to produce BRs in a liverwort. $M$. polvmorpha. Therefore. it is thought that the biosynthetic pathway to BRs in higher plants, at least the C6-oxidation pathway, is evolved from that in lower plants. To complete the genesis of BRs biosynthesis in plant kingdom, demonstration of the presence of the skipped biosynthetic pathway from 2 to 4 via 3 in Marchontia cells is underway now.

\section{Experimental Section}

Purification of in vivo metabolites of $\left[{ }^{2} \mathrm{H}_{6}\right]-6 .\left[{ }^{3} \mathrm{H}_{6}\right]-6(50$ $\mu \mathrm{g})$ was added to suspension-cultured cells (15 g) of $M$. polymorpha. ${ }^{10}$ After 1 week, the cells were harvested and extracted with $80 \%$ methanol $(100 \mathrm{~mL} \times 3)$. The extract was reduced to aqueous phase. combined with the culture media $(30 \mathrm{~mL})$. and re-extracted with chloroform $(100 \mathrm{~mL} \times 3)$. The chloroform soluble extract was concentrated and partitioned between $n$-hexane and $80 \%$ methanol. The biological active $80 \%$ methanol fraction was evaporated. and partitioned again between phosphate buffer $(0.1 \mathrm{M}, \mathrm{pH} 7.8)$ and ethyl acetate. The ethyl acetate soluble fraction was then loaded on a silica gel $(20 \mathrm{~g}$. Merck Co. $)$ colunn. Elution was carried out with every $100 \mathrm{~mL}$ of chloroform, 1. 2, 3. 4. 5, 6 . $7,8,9.10,50 \%$ methanol in chloroform. The fraction $4-6 \%$ methanol in chloroform shown BR-activity was combined and subjected to CI8 bulk chromatography $(100 \mathrm{~mL}$. Waters. Preparative C 18 ) that was eluted with 50.60.70.80. 90 and $100 \%$ methanol. The fraction eluted $70-90 \%$ methanol was further purified by a reversed phase HPLC (Senshu Pak Pegasil-B, $10 \times 150 \mathrm{~mm}$ ) at a flow rate $2.5 \mathrm{~mL}$ $\mathrm{min}^{-1}$ using aqueous acetonitrile as a mobile phase $(0-20$ min: $45 \%, 20-40 \mathrm{~min}$ : gradient to $100 \%$, and then $100 \%$ ). The HPLC fractions were collected every min and analyzed by a Preparative F254 TLC (Merck. Co) developed with a mixture of methanol-chloroform (1:6). After treatment of $70 \%$ sulfuric acid followed by heating. BR-like purplebluish spots were detected in the HPLC fraction 42-43. 5052 and 55-56. The fractions were analyzed by GC-MS/SIM

Enzyme preparation and assay. Suspension cultured cells ( $15 \mathrm{~g}$ ) of $M$. polymorpha were homogenized with $\mathrm{Na}$ phosphate buffer ( $\mathrm{pH} 7.4$ ) containing $250 \mathrm{mM}$ sucrose. 15 mM 2-mercaptoethanol. $1 \mathrm{mM}$ EDTA. $40 \mathrm{mM}$ ascorbate. 1 $\mathrm{mM}$ dithiothreitol. $0.1 \mathrm{mM}$ phenylmethylsulfonyl fluoride. $15 \%(\mathrm{v} / \mathrm{v})$ glycerol and $1 \%(\mathrm{w} / \mathrm{v})$ insoluble poly vinylpyrrolidone. The homogenate was filtered and centrifuged at $15.000 \times \mathrm{g}$ for $20 \mathrm{~min}$. The resulting supernatant was collected and used as a crude enzyme solution to examine enzymatic transformations in the study

In vitro enzymatic conversions were undertaken by addition of $6(5 \mu \mathrm{g} \times 3)$ to the crude enzyme solution $(500$ $\mu \mathrm{L} \times 3$ ) The assay mixture was incubated at $37^{\circ} \mathrm{C}$ from 30 min. and enzyme products were extracted with ethyl acetate after adding $\left[{ }^{3} \mathrm{H}_{6}\right]-4$. -5 and -7 as intemal standards for quantitative analysis. The obtained etlyl acetate soluble fraction was concentrated. re-dissolved in $50 \%$ methanol (10 $\mathrm{mL}$ ). and loaded on Sep-Pak Cl8 (Waters Co.) cartridge eluted with aqueous methanols $(10 \mathrm{~mL}$ each, 50.60 and $100 \%$ ). The fraction eluted with $100 \%$ methanol that showed a BR-activity was subjected to a reversed phase HPLC (Senshu Pak Pegasil-B. $10 \times 150 \mathrm{~nm}$ ) at a flow rate $2.5 \mathrm{~mL}$ $\mathrm{min}^{-1}$ using aqueous acetonitrile as a mobile phase $(0-20$ min: $45 \%, 20-40 \mathrm{~min}$ : gradient to $100 \%$. and then $100 \%$ ). The HPLC fractions $42-43$ and $50-52$ were collected and analyzed by GC-MS/SIM.

GC-MS/SIM analysis. Metabolites of $\left[{ }^{2} \mathrm{H}_{i j}\right]-$ and $\left[{ }^{7} \mathrm{H}_{6}\right]-6$ were analy zed by a 5973 mass spectrometer $(70 \mathrm{eV}$. HewlettPackard) connected to 6890 gas chromatography fitted with a fused silica capillary column (HP-5. $0.25 \times 30 \mathrm{~m}$. $0.25 \mu \mathrm{m}$ film thickness). GC conditions in the analyses were as follow: on-columm injection mode; $\mathrm{He} 1 \mathrm{~mL} \mathrm{~min}{ }^{-1}$; oven temperature, $175^{\circ} \mathrm{C}$ for $2 \mathrm{~min}$, thermal gradient from $175^{\circ} \mathrm{C}$ to $280^{\circ} \mathrm{C}$ at $40 \mathrm{~min}^{-1}$. and then $280^{\circ} \mathrm{C}$. Prior to injection, samples were derivatized to be a methaneboronate $(\mathrm{MB})$ or MB-trimethylsilylic ether (TMSi). ${ }^{11}$

Acknowledgement. This work was supported by Korea Research Foundation Grant (KRF-2001-015-DP0483).

\section{References}

1. Kim. Y.-S.; Yun. H. S.: Kim. T.-W.: Joo, S.-H.; Kim, S.-K. Bull. Kowan Chem. Soc. 2002. 23(7). 941

2. Kim. Y.-S.: Kim. S. Y.: Kim. S.-K.: Shim. J. K. Bull. Korean Chent Soc. 2002. 23(10). 1473 .

3. Kim. S.-K; Kim. Y.-S.: Kim, T.-W.; Joo, S.-H.: Shim. J. K. Bull. Koman Chem. Soc. 2001. 22(12), 1299.

4. Yokota, T.: Kim, S.-K.: Fukui. Y.: Takahashi. N.: Takeuchi, Y. Takematsu. T. Phvtochemistry 1987. 26.503.

5. Yokota. T:: Ogino. Y: Takahashi. N.: Saimoto. H.: Fujioka. S.: Sakurai. A. Agric. Biol. Chem. 1990. 5t. 1107.

6. Choi. Y. H: Fujioka, S.; Nomura. T.; Harada, A.; Yokota, T.: Takatsuto. S.: Sakurai. A. Phytochemistry 1997. 14.609.

7. Sakurai. A. Brassinosteroids: Steroidal Plant Hormones' Sakurai. A.. Yokota. T.. Clouse. S. D.. Eds.: Springer-Verlag: Tohyo. 1999. p 91.

8. Suzuki. H.: Fujioka. S.: Takatsuto. S.: Yokota. T.: Murofushi. N.: Sakurai. A. Plont Ghow th Regul. 1994, 13, 21

9. Kim. Y.-S.: Kim. T.-W.: Kim. S.-K. Bull. Koman Chem. Soc. 2003 (in press)

10. Ohta. Y.: Katoh. K.: Miyaki. K. Planta 1977. 136. 229

11. Park. S.-H.: Han1. K.-S.: Kim. T.-W.: Shim. J.-K.: Takatsuto. S.: Yokota. T.: Kim. S.-K. Plan Cell Phnsiol 1999. 40(9). 955.

12. Arima, M.: Yokota. T.: Takahashi, N. Phyochemistry 1984, 208, 1 .

13. Kim. T.W.: Park. S.-H.; Joo, S.-H.: Kim, Y.-S.: Choo, J '; Kim, S.K. Bull. Korean Chem. Soc. 2001, 22(6), 651 . 